PRZEGLĄD BIBLIOTECZNY 2020 e-ISSN 2545-2487

\title{
THE NATIONAL LIBRARY OF POLAND DURING THE CORONAVIRUS PANDEMIC: A BRIEF HISTORY OF THE FIRST NINE MONTHS OF THE STATE OF EMERGENCY
}

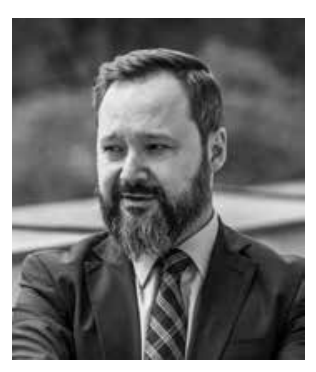

Tomasz Makowski, dr, Director General of the National Library of Poland since 2007, head of the Polish National Library Board and the National Reserve of Library Collections Committee. Editor-in-Chief of the journals Polish Libraries and the Yearbook of the Polish National Library. Chair of the Board of the Museum of Warsaw, Co-Chair of the Intergovernmental Polish-Ukrainian Subcommittee on Library Affairs, Vice-Chair of the Polish Committee of the UNESCO Memory of the World Programme. Honorary Member of the Association internationale de bibliophilie and the FIDES Federation. Author of four monographs and numerous research articles. Expert in manuscripts and the history of libraries.

KEYWORDS: Pandemic. National Library of Poland. BNP. Cooperation between libraries. Recommendations for libraries. COVID-19. Pandemic.

ABSTRACT: Thesis/Objective - This article describes the situation of the National Library of Poland (BNP) during the first nine months of the COVID-19 pandemic. The BNP played multiple roles at the same time: as the biggest library in Poland it provided readers with safe access to its unique collections; it acted as the central body for cataloguing the latest publications for libraries in Poland; and as the country's central state library it issued recommendations for the 30,000+ libraries across Poland. Results/Conclusions - A paramount concern was ensuring the safety of the employees and readers of the BNP and other Polish libraries, as well 
as issuing instructions on what libraries should be doing during the pandemic. The BNP offered support for institutions which found themselves at a loss under these extraordinary circumstances. The BNP maintained its key activities during the period, especially cataloguing the legal deposit intake of new publications.

This article describes the situation of the National Library of Poland (Biblioteka Narodowa Polski, BNP) during the first nine months of the COVID-19 pandemic. However, I should begin with one important reservation. At the time of writing it is unclear how long the pandemic will last, and it is possible that the way it develops will soon make the measures, plans and fears described here obsolete one way or the other.

From the very outset it was essential to make a rational assessment of the situation, putting our fears on one side. Western societies were facing, for the first time in living memory, the prospect of a pandemic and few had even read about such events in historical or literary works. We very quickly realised that standard actions would not be enough. Literally overnight we had to rethink the functioning of the library both as an entity in itself, one of many libraries in Poland, and as the country's central state library.

As nothing was known about the virus at the time, the scientists could not provide the authorities and bodies responsible for healthcare - let alone libraries - with reliable information as to which activities should be stopped immediately, which should be limited and which could carry on as normal. Protecting the health service and ensuring that it had sufficient capacity was the most important thing. All other activities needed to be subordinate to this goal until such time as reliable information was available both about the virus itself and about how it might develop.

Our paramount concern was to ensure the safety of our employees and readers: this formed the basis for determining which services we should provide. We knew that the pace of the epidemic and the unprecedented scale of the global threat meant that we could not simply wait for guidance to be issued by the official bodies, beyond a general plan of action. Our view was that each of us should anticipate the possible needs and potential dangers relating to our own specific area of work. The rise in the number of infections and above all the lack of basic information about the virus itself - how deadly it was, how it was transmitted, which groups were the most vulnerable, what were the possible short and long-term complications, and so on - meant that we needed to take action without delay, as prudently and safely as possible.

It was important for us to embrace responsibility rather than trying to shirk it. In an extraordinary situation such as this, our employees might be afraid and they needed to know that any decisions we took were both justified and necessary. It seemed to us that one of the biggest dangers 
would be trying to keep things the way they were, in other words, a situation in which we knew that the virus was dangerous but did not take any action, because no-one had told us what to do. Today, nine months on, we know that the virus will be around for some time to come. According to optimistic forecasts a drug treatment or vaccine will be ready by autumn 2021. That means that the BNP and other libraries will have to live with the virus for at least another year. We need to prepare for radical changes. Much will change about our business in the near future, and much needs to change in order for us to continue operating as before. We must accelerate the digital revolution taking place in our libraries.

The issue of the coronavirus was raised for the first time at the meeting of the Kolegium (management board) of the $\mathrm{BNP}^{1}$ on March 3. In light of the large number of cases of coronavirus-related diseases occurring across the world, the risk of an epidemic was taken very seriously and the situation monitored daily. Our initial actions were based on the recommendations of the World Health Organisation (WHO). First and foremost, managers and through them other members of staff - were kept up to date about the situation and possible safeguards against infection. In the early days this meant issuing reminders about maintaining a high level of hygiene, above all washing hands thoroughly and often and ventilating rooms. We turned up the water temperature in the sinks in the library's toilets to make it easier to kill viruses by washing hands. We also fitted dispensers with hand sanitizers, put up instructions about how to wash hands properly and disinfected door-handles and the surfaces of desks and tables in our offices and reading rooms. We reminded employees to clean their work computers themselves, including disinfecting keyboards and mice, and told them that the necessary liquids for doing so were available in the library. We told them that anyone with a cold should take special precautions when dealing with their colleagues in order to reduce the risk of spreading infection ${ }^{2}$. At this time we also slowly started shifting some employees to working from home (remote work).

The meeting of the Kolegium on March 10 was an important milestone. At the meeting key decisions aimed at stopping the spread of the virus were announced ${ }^{3}$. Seminars, conferences, training courses and all events involving a large number of people were cancelled, first temporarily and

\footnotetext{
${ }^{1}$ According to the BNP's statutes the Kolegium is made up of the directors, deputy directors, heads of institutes, departments, offices and other organisational units, in addition to other individuals whose work is essential to the functioning of the BNP.

${ }^{2}$ Protokół nr 9 posiedzenia Kolegium Biblioteki Narodowej z dnia 3 marca 2020 r. (9th Minutes of the Meeting of the Kolegium of the BNP, March 3, 2020).

${ }^{3}$ Actions were taken in line with the recommendations of the Ministry of Culture and National Heritage and in constant consultation with the Department of State Patronage monitoring the activities of libraries in Poland.
} 
then until further notice ${ }^{4}$. This decision was dictated by the need to minimise the risk of the virus spreading among BNP staff and visitors. Our chief recommendation was to keep direct contact between individuals to a minimum, communicating via email or telephone instead. It was already known at the time that some cases of coronavirus infection were asymptomatic, so we decided to keep staff apart as much as possible, not just by having some of them work from home but also by putting those who remained in rooms on their own and not allowing them to visit the rooms of other members of staff. The BNP took the view that although it could not protect individuals from infection at home, on public transport or in shops, for instance, it could stop transmission of the virus between members of staff by isolating them from each other. Above all, the management and heads of departments worked hard to reorganise work quickly so that staff could perform the most important tasks at home. A key decision one that was taken quickly, early on in the process - was to buy a large number of laptops before they disappeared from the market. Employees who had symptoms of any type of infection were instructed to stay at home; if they had any symptoms typical of the coronavirus, they should stay at home and immediately call the local District Sanitary and Epidemiological Station to find out about recommended further treatment. The BNP's Kancelaria (Administrative Office) provided information about the precautions that should be taken when dealing with Post Office workers and couriers delivering parcels. Employees aged over 60, a high-risk group, were the first for whom arrangements were made to work form home. The Director General of the BNP, Tomasz Makowski, also asked the heads of departments to check if any retired BNP employees who were living alone needed help.

It was decided to suspend all non-essential business trips, initially on a temporary basis and then until further notice. Staff members currently away on business trips were given guidelines on how to minimise the risk of falling ill. In particular, a team of four female members of staff were working on the digitisation of the collections of the Kultura Literary Institute at Maisons-Laffitte near Paris, which was affected by the epidemic. This is part of a long-term project financed by the Ministry of Culture and National Heritage on the basis of an agreement between the BNP and the Kultura Literary Institute; the collections themselves are listed on the UNESCO Memory of the World Register. After many problems, the team managed to return to Poland on May $13^{5}$.

${ }^{4}$ The Director General of the BNP, Tomasz Makowski, instructed those responsible for organising events at the BNP to inform participants that all meetings were cancelled and to warn speakers who were scheduled to give talks in the following two months about possible changes to the schedules of seminars and conferences.

${ }^{5}$ Protokół nr 13 posiedzenia Kolegium Biblioteki Narodowej z dnia 19 maja 2020 r. (13th Minutes of the Meeting of the Kolegium of the BNP, May 19, 2020) 
Another key decision was arranging for the almost 80 individuals involved in cataloguing the legal deposit intake of new publications to be able to work from home, and organising a designated driver to continually deliver and collect copies of the publications for cataloguing. This required a major effort on the part of the Zakład Katalogowania Dziedzinowego (Department of Domain-based Cataloguing), the Zakład Wypożyczania Krajowego i Zagranicznego (Domestic and International Lending Department) and the Zakład Administracyjno-Gospodarczy (Administrative and Economic Department) $)^{6}$. The BNP wanted to maintain its standard of cataloguing incoming publications for the legal deposit within 24 hours one of the BNP's great achievements - and also continue cataloguing all multi-author publications, such as post-conference volumes, and articles from 2,500 scientific and cultural journals. In the subsequent weeks and months it was not always possible to maintain this 24-hour turnaround time due to publications arriving for the legal deposit at irregular intervals, but the turnaround time was never more than a week and usually books were catalogued within 48 hours of receipt by the BNP.

Taking into account the recommendations of the health authorities, the Library's Director General, Tomasz Makowski, decided to limit the number of places in the reading room so that the distance between readers could be increased to 1.5 metres. It was also decided that staff accepting items returned by readers should wear gloves. Relevant announcements were published on the BNP website and the staff website ${ }^{7}$.

The next day, March 11, 2020, Tomasz Makowski cancelled his trip to attend a ceremony at the Municipal Library in Elblagg, and called another meeting of the Kolegium and a meeting of the Crisis Management Team. He announced that the Library would be completely closed to visitors from March 12-25, 2020, including the reading rooms, and that this period of closure might be extended. He further stated that no training courses, conferences, meetings with external guests or domestic or foreign trips by employees would take place at the BNP until April 13, 2020. If their jobs allowed it employees should work from home, in agreement with their superiors and subject to the relevant regulations. If the nature of their jobs made working from home impossible, employees could be entrusted with the job of creating records of copies of journals. Support was available

\footnotetext{
${ }^{6}$ Special mention must be made here of the contribution of Karolina Łuczyńska, who in the early days of the pandemic took over the management of the Zakład Katalogowania Dziedzinowego (Department of Domain-based Cataloguing) and did an excellent job organising the work under the leadership of Kacper Trzaska, Deputy Director of the BNP in charge of supervising cataloguing. Barbara Morawiec also did an outstanding job organising the Zakład Wypożyczania Krajowego i Zagranicznego (Domestic and International Lending Department) so that copies could be transported to and from cataloguers quickly and efficiently.

${ }^{7}$ Protokół nr 10 posiedzenia Kolegium Biblioteki Narodowej z dnia 10 marca 2020 r. (10th Minutes of the Meeting of the Kolegium of the BNP, March 10, 2020)
} 
from the Zakład Czasopism (Department of Journals). Heads of departments should consider reorganising the work, taking into account the nature of their unit and the skills of their employees, so that members of staff could look after family members and limit their contact with other people on their way to work. It was announced that all desks were occupied in the temporary reading room, services were operating smoothly and there were no queues. Tomasz Makowski decided to suspend the online ordering of publications and recommended redirecting readers towards the POLONA digital library and other electronic resources. Monika Mitera, Deputy Director of the BNP, drew attention to the Act of March 2, 2020, on specific solutions to prevent, counteract and combat COVID-19, other infectious diseases and crisis situations caused by them (Journal of Laws, item 374), which among other things provided for the introduction of a special care allowance for a maximum of 14 days for one of the parents caring for a child under eight years of age due to the closure of a crèche, children's club, kindergarten or school. It was noted that the Biuro Spraw Pracowniczych (Office of Employee Affairs) would post detailed information on the staff website together with an example of the statement that should be submitted in order to claim this benefit. Occupational Health and Safety Service (Służba BHP) announced that staff in direct contact with readers and returned items from the Library's collections would be provided with personal protective equipment in the form of gloves. It was noted that the Occupational Health and Safety Service (Służba BHP) was in contact with the Chief Sanitary Inspectorate (Główny Inspektorat Sanitarny, GIS), which had that day confirmed that the precautions and prevention measures put in place at the BNP were for the time being sufficient.

Tomasz Makowski asked the heads of departments for an update on the situation in each of their departments. No serious problems were reported. In view of the government decision to suspend the activities of cultural institutions, he asked the heads of the departments to come to an agreement with museums about the starting dates of exhibitions that involved loans from the BNP.

Tomasz Makowski invited everyone to the next meeting of the Crisis Management Team, and to the meeting of Kolegium the same day at 3.30 p.m. The break was used for a meeting with the heads of the trade unions to discuss the situation with regard to the pandemic. During the early days of the pandemic, Tomasz Makowski and the Deputy Director of the BNP met with the trade unions many times to agree next steps and to communicate any decisions that had been taken.

Throughout the day the reading rooms were well occupied, despite the new sanitary regime and the required distance of 1.5 metres between readers. A decision was taken to speed up the transportation of early printed books from the Palace of the Commonwealth to the main building of the 
Library $^{8}$. Unfortunately, despite these efforts, there came a point when the transportation had to be stopped; it was resumed in June when the level of infections had fallen, and completed in August.

On March 11 the BNP announced that it was cancelling all conferences, seminars and training courses up to April 13, 2020, and recommending other libraries to take similar decisions and implement preventative measures to reduce the epidemiological risk associated with the SARS-CoV-2 coronavirus.

On the same day, the Government Crisis Management Team, of which the Minister of Culture and National Heritage was a member, decided to close all cultural institutions, concert halls, opera houses, operetta theatres, other theatres, museums, cinemas, community centres, libraries, art galleries, schools, universities, colleges and art education institutes from March 12, 2020, on a temporary basis ${ }^{9}$. The BNP immediately informed other libraries about this decision via its website and social media.

Now closed, the BNP decided to bring its digital resources to bear for the benefit of both its own readers and those of other libraries. On March 13 the Library launched a campaign advertising the POLONA digital library under the slogan Czytanie on-line bez ryzyka zakażenia. Największa biblioteka cyfrowa w Polsce otwarta ("Read online without the risk of infection. Poland's largest digital library is open.") POLONA has over three million digital items: books, journals, manuscripts, early printed books, maps, drawings, graphics, photographs, postcards, sheet music and ephemera. It is currently one of the largest digital libraries in Europe. In 2019 the BNP was ranked second among Europe's national libraries in terms of the number of digital scans made each year.

On the evening of Friday, March 13, the Rozporządzenie Ministra Zdrowia z dnia 13 marca 2020 r. w sprawie ogłoszenia na obszarze Rzeczypospolitej Polskiej stanu zagrożenia epidemicznego (Ordinance of the Minister of Health of March 13, 2020, declaring a state of epidemic threat on the territory of the Republic of Poland) was published ${ }^{10}$. During the night, Tomasz Makowski and Deputy Director Dominik Cieszkowski carefully went through this lengthy document, each of them working independently of the other; in the morning Monika Miter, Deputy Director for Scientific Affairs, joined in the task. On the Saturday, after agreeing on how the regulations should be interpreted and what the possible problems for the Library staff were, they asked Professor Hubert Izdebski, an outstanding legal expert, long-standing Director of the Instytut Nauk

\footnotetext{
${ }^{8}$ Protokół nr 12 posiedzenia Kolegium Biblioteki Narodowej z dnia 11 marca 2020 r. (12th Minutes of the Meeting of the Kolegium of the BNP, March 11, 2020)

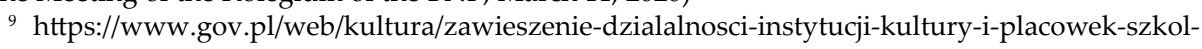
nictwa-artystycznego

${ }^{10} \mathrm{https} / / /$ dziennikustaw.gov.pl/D2020000043301.pdf
} 
o Państwie i Prawie (Institute of State and Law Studies) of Warsaw University and Member of the Scientific Council of the BNP, to draw up a legal opinion that libraries could use when talking to the local authorities under whose control they fell. On the basis of this legal opinion, which was sent on Monday morning, the BNP then drew up an official statement on the activities of public libraries in the light of the aforementioned ordinance. This official statement by the BNP was used by many libraries not only in their interpretation of the regulations but in the difficult discussions they held with local authorities, who sometimes wanted to interpret the ordinance to the disadvantage of the libraries and their staff. Thanks to the official statement by the BNP it was possible to ensure fairly consistent library operations throughout the country and avoid differences between the decisions in different areas.

The BNP's official statement said that libraries should aim to perform remotely, to the maximum extent possible and within the regulations in question, the duties necessary for the functioning of the library.

Specifically, the BNP recommended that libraries carried out the following tasks remotely:

- Communicating with readers via email and answering queries using online sources

- Improving and expanding their online catalogues by copying records from the combined catalogues of the BNP, the Jagiellonian Library and regional libraries in Kielce and Lublin, available on the BNP website and via data.bn.org.pl

- Expanding the contents of their own websites (for example using the resources of the BNP and POLONA to identify items relating to local history or creating their own collections based on the contents of POLONA)

- Reading specialist publications such as reports on the situation with regard to libraries and reading as a whole, and familiarising themselves with new cataloguing regulations and changes in the BNP's descriptors (przepisy.bn.org.pl)

- Planning purchases by looking at websites announcing new and forthcoming publications

- Developing potential activities, workshops for children and adults, lessons and training courses that could be offered once the threat subsided

- Running information campaigns about online resources such as POLONA on their website and social media

- Writing articles, reviews and reports about the state of reading in their own municipality, district and so on 
- Preparing marketing materials for use after the epidemic

- Creating or participating in online courses ${ }^{11}$.

It should be noted that the BNP's actions covered two distinct areas: it had to work out internally what its own role and activities should be during the pandemic and, in parallel, it had to provide assistance to over 30,000 libraries in Poland. Thanks to a number of quick decisions taken early on, the situation at the BNP did not get out of control. Tomasz Makowski set out the decisions concerning BNP employees and established the longer-term principles on which the Library would now operate in the Zarzadzenie $n r$ 41/2020 z dnia 17 marca $2020 \mathrm{r}$. w sprawie działan zapobiegawczych podejmowanych $w$ Bibliotece Narodowej w celu przeciwdziałania narażeniu pracowników Biblioteki Narodowej na zakażenie wirusem COVID-19 (Regulation No. 41/2020 of March 17, 2020, on preventative actions taken at the National Library of Poland to prevent exposing its employees to the COVID-19 virus). This decree remains in force at the time of writing ${ }^{12}$.

On the evening of Friday, March 20, the Rozporządzenia Ministra Zdrowia z dnia 20 marca 2020 r. w sprawie ogłoszenia na obszarze Rzeczypospolitej Polskiej stanu epidemii (Ordinance of the Minister of Health of March 20, 2020, declaring a state of epidemic on the territory of the Republic of Poland) was published, banning library activities until further notice. In fact, such a ban was already included in the March 13 ordinance, but on a temporary basis ${ }^{13}$. Naturally this also meant closing the BNP reading rooms until further notice.

On Monday, March 23, following the decision to close libraries indefinitely, the BNP issued a statement concerning making preparations for their reopening. The purpose of this statement was first and foremost to get librarians to use their free time to prepare for the way they would be operating once they reopened. The statement said that due to the need to break the transmission chain of the coronavirus, a decision had been made to close libraries in Poland until further notice. Since March 13, libraries had not been allowed to operate reading rooms or lending services, including accepting returned items. The BNP gave the following recommendations concerning the handling of returned items when libraries did reopen, based on the very limited knowledge about the virus at the time:

The SARS-CoV-2 virus can survive for some time outside the human body. This means that surface contamination of publications is also possible.

We recommend that libraries apply the following rules when handling items from their collections which are returned by readers:

11 https://www.bn.org.pl/w-bibliotece/3930-opinia-biblioteki-narodowej-dotyczaca-ograniczeniadzialalnosci-bibliotek-publicznych.html

12 October 30, 2020

${ }^{13}$ https://dziennikustaw.gov.pl/D2020000049101.pdf 
- Staff should wear latex or nitrile gloves when receiving returned copies lent out to readers

- Only touch copies directly in order to identify them

- Do not disinfect returned publications with detergent or alcohol-based disinfectants

- Returned copies should be "quarantined" for 10-14 days

- Disinfect any surfaces that come into contact with returned materials by washing them with detergent or a disinfectant containing at least 60 percent alcohol

- In the event of a member of staff who is in contact with the collections being infected with the SARS-CoV-2 coronavirus, 10-14 days' quarantine must be observed and that part of the collections which the member of staff was in contact with must not be used

Quarantining all copies returned after libraries reopen should ensure that the work carried out is safe.

- The following general safety rules should also be observed:

- Wash your hands properly with soap and water for at least 30 seconds

- Avoid touching your face (eyes, nose, mouth)

- Keep a safe distance (one to two meters) from other people

- When sneezing or coughing, cover your mouth and nose with a disposable handkerchief, then throw the handkerchief away

- If you show any symptoms of having a viral disease (fever, coughing, difficulty breathing) seek medical assistance, in the first instance by telephone ${ }^{14}$.

Following the publication in April of the results of a new study on the Sars-CoV-2 coronavirus, on May 4 the BNP issued an announcement amending its recommendations regarding the quarantining of books and other publications in libraries. In the announcement it stated that the virus remained active for up to 72 hours (three days) on plastic surfaces such as book covers, CDs and so on. The recommendations relating to cardboard and paper, where the virus can survive for up to 24 hours, were not changed. The other recommendations for protecting against the virus also remained unchanged. The authors of the studies on which the shortening of the recommended quarantine period was based themselves advised caution when interpreting their results, so the BNP recommended using a longer period of quarantine if possible and treating the period of three days as a minimum. The BNP reminded libraries that returned books should be put aside in a box, container or bag or on specially designated shelves in the stores, some other room or a bookcase. Quarantined items should be marked with the date when they were returned and not lent html.

${ }^{14}$ https://www.bn.org.pl/aktualnosci/3938-bezpieczenstwo-epidemiczne-w\%26nbspbibliotekach. 
out again until the quarantine period was over, after which they could be put back into circulation. Gloves should be worn. Separate "quarantine rooms" were not required as the virus could not spread unassisted. Copies returned to the library by readers should not be disinfected with disinfectants. Ozone should not be used to disinfect books as it had oxidising properties that were harmful to cellulose materials. UV lamps should not be used on books as the UV light had a detrimental effect on the materials from which books were made. The BNP also reminded libraries that each time returned books were received from readers, the counter on which they were placed should be disinfected ${ }^{15}$.

On April 19, 2020, a Rozporządzenie Rady Ministrów (Ordinance of the Council of Ministers) was published extending the period of closure of libraries until the start of the second phase of lifting the COVID-19 restrictions ${ }^{16}$. It was not stated when this would be as it would depend on the situation with regard to the epidemic. On April 29, Prime Minister Mateusz Morawiecki announced that the second phase of lifting restrictions would begin on May 4, 2020; in other words libraries could reopen on that date.

The same day, May 4, the BNP announced that decisions to reopen libraries should be taken by the director of the library in question in consultation with the local authorities, ministers and the State Sanitary Inspectorate (Sanepid). Reopening should take place when the library had taken the necessary steps to be able to function safely during the epidemic. The decision should take into account the number of users and local factors, including the size of the room to be accessed by users. The BNP recommended operating a lending facility only. Until the number of infections fell significantly or the state of epidemic was ended, it did not recommend reopening reading rooms or allowing free access to card catalogues, books or journals. It would make a separate announcement about the reopening of reading rooms once the number of infections had fallen, after consultation with health services.

The BNP reminded libraries that although books were printed on paper, their covers (for example in the case of varnishing) were made of plastics, so the virus could survive on their surfaces much longer than on paper. Both users and librarians were advised to wear masks and gloves while in the library. Readers should reserve a specific time slot by phone or email in order to avoid queues. A protective screen (for example made of Plexiglas) should be installed at the point of contact between users and librarians, for example on the library desk. Users showing any signs of illness or who find themselves among a group of people who are not required to

\footnotetext{
15 https://www.bn.org.pl/aktualnosci/3978-skrocenie-okresu-kwarantanny-ksiazek-w-bibliotekach-do-3-dni.html

${ }^{16}$ https://dziennikustaw.gov.pl/D2020000069701.pdf.
} 
wear masks should stay at a safe distance. Libraries were encouraged to provide a hand-washing and disinfection station where possible, plus access to disposable gloves and masks. Where librarians did not have access to masks, gloves and disinfectant, the BNP recommended that they should simply not reopen, even for lending only.

Each time books were returned by users, the counter which they were placed should be disinfected as the virus could survived up to 14 days on stone surfaces. Returned books should be put aside for three days ${ }^{17}$ in a box, container or bag or on specially designated shelves in the stores, some other room or a bookcase. Quarantined items should be marked with the date when they were returned and not lent out again until the quarantine period was over, after which they could be put back into circulation. Gloves should still be worn when handling books. Separate "quarantine rooms" were not required as the virus could not spread unassisted. Copies returned to the library should not be disinfected with disinfectants. In addition, it was recommend that rooms should be ventilated and "biblioboxes" (self-service boxes for book returns), door handles, keyboards, telephones, light switches and other frequently used surfaces or equipment should be disinfected as often as possible.

The BNP announcement of May 4 further stated that it was imperative that library staff complied with the preventative rules issued and updated by the Chief Sanitary Inspectorate and the Ministry of Health. Instructions about washing hands, disinfecting hands and how to put on and take off protective masks, available from the website of the Chief Sanitary Inspectorate (GIS), should be displayed where readers would see them. If a member of the library staff became infected with the coronavirus, the procedures outlined by the Chief Sanitary Inspectorate should be followed. The BNP recommended encouraging readers to use the resources available online ${ }^{18}$.

In addition, the BNP set up an "advice centre" to answer questions about the activities of libraries in relation to the pandemic. Frequently asked questions were also published on the website ${ }^{19}$.

On April 30, the BNP announced that until the number of infections fell significantly and the fourth phase of lifting COVID-19 restrictions was announced, the BNP's reading rooms would remain closed to readers. Modernisation works had been ongoing in the reading rooms since 2018 and the collections had been available in small temporary reading rooms, where it was not possible to guarantee safety with regards to the epidemic. Users were encouraged to use the online resources on POLONA.PL and

\footnotetext{
${ }^{17}$ In the announcement of April 29 this was 10-14 days; on May 4 it was changed to three days.

${ }^{18}$ https://www.bn.org.pl/aktualnosci/3971-od-4-maja-mozna-otwierac-biblioteki.html

${ }^{19}$ https://www.bn.org.pl/aktualnosci/3972-poradnia-biblioteki-narodowej.html
} 
other libraries' lending facilities, which could reopen from May 4, $2020^{20}$. At the same time the BNP recommended that other libraries open their reading rooms during the fourth phase of lifting COVID-19 restrictions ${ }^{21}$.

On May 2, 2020, a Rozporządzenie Rady Ministrów (Ordinance of the Council of Ministers) was published lifting the ban on library activities from May 4, as had been announced the previous Wednesday. In this connection the BNP reminded libraries that the guidelines for the operation of libraries during the COVID-19 epidemic in Poland issued by the Ministry of_Development in consultation with the Chief Sanitary Inspectorate on April 28, 2020 and contained in the announcement by the Ministry of Culture and National Heritage should be regarded as obligatory. According to these guidelines, the decision to reopen a library and when to do so should be taken by the director of the library in consultation with the with the local authorities and sanitary inspector, by phone or email. The consultations with the sanitary inspector should cover issues of how the work was to be organised after the library reopened in terms of meeting the conditions outlined in the guidelines and the recommendations of the BNP (for example concerning long-term staff illness, small library spaces and difficulties maintaining distance between users) and any other sanitary issues relating to the specific nature of the library's activities ${ }^{22}$.

On May 11 the BNP launched its new "Digitisation on demand" service, inviting anyone interested to submit their suggestions about what material they needed digitised, be it for their day-to-day work, the purpose of study or their hobbies. The BNP provides this service free of charge. Only library materials in the public domain can be digitised, in other words material in respect of which the economic rights set out in the Act on Copyright and Related Rights have expired or which were not subject to copyright in the first place. This applies primarily to publications created more than 70 years after the author's death (currently persons who died before January 1, 1950). Access to publications via POLONA was also possible if the authors or their heirs transferred the relevant licences to the $\mathrm{BNP}$, something which the BNP encouraged them to $\mathrm{do}^{23}$. At the beginning of the campaign there were more than 100 submissions a day, which were implemented on an ongoing basis ${ }^{24}$.

\footnotetext{
${ }^{20}$ https://www.bn.org.pl/aktualnosci/3973-czytelnie-biblioteki-narodowej-zostana-otwarte-dlaczytelnikow-w-iv-etapie-znoszenia-ograniczen.html

${ }_{21}$ https://www.bn.org.pl/aktualnosci/3976-otwarcie-czyteln-w-bibliotekach-w-iv-etapie-znoszenia-ograniczen.html

${ }^{22}$ https://www.bn.org.pl/aktualnosci/3977-rekomendacja-bn-dotyczaca-konsultacji-bibliotek-z-inspektorami-sanitarnymi.html

${ }^{23} \mathrm{https} / / /$ www.bn.org.pl/aktualnosci/3981-digitalizacja-na-zyczenie.html

${ }^{24}$ Protokół nr 13 posiedzenia Kolegium Biblioteki Narodowej z dnia 19 maja 2020 r. [13th Minutes of the Meeting of the Kolegium of the BNP, May 19, 2020]
} 
A summary of the first two months of the pandemic presented at the meeting of the Kolegium on May 19 reported that more than 45,000 articles from journals and multi-author publications, plus 1,500 copies of books for the legal deposit, had been catalogued remotely by the Zakład Katalogowania Dziedzinowego (Department of Domain-based Cataloguing) ${ }^{25}$.

At the meeting of the Kolegium on May 26, Tomasz Makowski recommended that the heads of departments adopt flexible rules concerning working from home, analysing the situation of specific employees on a case-by-case basis, including their ability to commute to work. He said that the fact that remote workers had to submit a daily progress report on their work meant that heads of departments could monitor whether the tasks entrusted to them were being carried out properly or not, but that these reports were also a tool for employees to monitor their own work. He recommended that heads of departments continued to require these progress reports ${ }^{26}$.

Following the announcement that the fourth phase of lifting COVID-19 restrictions would begin on June 6, 2020, the BNP published an announcement on May 28 recommending that libraries reopen their reading rooms for users. However, it encouraged libraries to allow readers to borrow items and take them home with them, rather than consulting them in reading rooms. The specific recommendations were are follows:

The decision about when to open reading rooms and under what conditions is to be taken by the director of the library. The decision should take into account the number of users, local conditions, how long users spend in reading rooms and the local situation with regard to the epidemic at a municipal, district and provincial level. It is also important that preventative measures are taken ensure the safety of both library staff and readers. The directors or managers of libraries may, in light of their authority to manage the library or their powers of attorney if the library does not have legal personality, introduce additional conditions for using the library.

The BNP reminds libraries that they should observe all rules relating to safety during the epidemic as issued and updated by the Chief Sanitary Inspectorate and the Ministry of Health.

The BNP recommends social distancing in all public areas of the library, both in smaller areas (such as corridors) and larger spaces (such as reading rooms) as far as the limitations of the library building itself allows. It is recommended to place markings (points or lines) on floors indicating a safe distance of two metres between people.

The BNP recommends providing a hand-disinfection station for readers before they enter the reading room, with appropriate instructions. We recommend that

\footnotetext{
${ }^{25}$ Ibid.

${ }^{26}$ Protokół nr 14 posiedzenia Kolegium Biblioteki Narodowej z dnia 26 maja 2020 r. [14th Minutes of the Meeting of the Kolegium of the BNP, May 26, 2020]
} 
librarians who are in contact with users wear disposable gloves. After disinfecting their hands, readers are not obliged to wear gloves while in reading rooms. Readers who are worried about being infected by touching books, especially reference works on open shelves, should be informed that they may wear gloves if so desired. Currently, the risk of coronavirus infection through contact with books is considered to be low. Some libraries in Europe have recently stopped quarantining books, but most maintain a three-day quarantine period for books returned by readers. The decision about whether to allow free access to books on open shelves should be taken by the director of the library, taking into account the local situation regarding the epidemic. This should not be allowed in areas where new infections are still appearing.

The BNP recommends that librarians and readers wear masks or visors while inside the library as the risk of infection while inside rooms is not yet considered low. For this reason it is also important to ventilate reading rooms.

The BNP recommends disinfecting the surfaces of desks in reading rooms, handrails, door handles and other surfaces frequently touched (for example light switches) and cleaning floors more often. In addition we recommend disinfecting computer workstations, keyboards and other computer equipment after each reader has used them, and likewise self-service scanners and multifunction devices, in line with the manufacturer's instructions.

As concerns reading rooms, the BNP recommends limiting capacity to 50 percent of the available places for readers while maintaining sanitary requirements and a two-metre distance between readers' desks. If it is not possible to move tables or desks further away from each other, we recommend installing protective screens between them, for example made of Plexiglas. The maximum number of people allowed in the reading room should be clearly displayed and seats that are not to be used should be marked as such.

The BNP recommends introducing breaks in the opening times of the reading room so that the room can be ventilated and surfaces, door handles and keyboards disinfected. To avoid queues and overcrowding we recommend that readers should have to book a specific time slot by phone, email or other messenger service.

The BNP recommends cancelling all subscriptions to print newspapers and weeklies and instead subscribing to them digitally until the end of the pandemic.

The BNP recommends installing a protective screen, for example made of Plexiglas, at the point of contact between users and librarians - on the library desk for instance. If possible, libraries should avoid any work that requires staff who are over the age of 60 or chronically ill coming into direct contact with people outside the library. The Duty Librarian or other designated staff member must disinfect the surface and other parts of the work station before and after dealing with each reader. Readers should only be served if they disinfect their hands before entering the reading rooms. The BNP does not recommend allowing readers whose are visibly sick to enter the library; in this case the procedures outlined by the Chief Sanitary Inspectorate should be implemented immediately. 
The BNP recommends encouraging readers to use online services such as Academica, POLONA and other digital libraries and databases, and granting access to commercial digital resources. We also encourage libraries to inform readers about the option of using the free "Digitisation on demand" service.

The BNP does not recommend engaging in traditional interlibrary loans due to potential difficulties with deliveries both within Poland and abroad, the need to implement a quarantine procedure for items and limitations on making publications available in reading rooms. We recommend providing a terminal with access to the Academica interlibrary loan system, which is free of charge for libraries and readers ${ }^{27}$.

The BNP encourages library staff to continue working from home and to replace direct contacts with contact via email, telephone or other messenger service where possible. We do not recommend organising conferences, seminars or meetings unless they can be held online ${ }^{28}$.

The same day, May 28, the BNP announced the launch of a newsletter entitled Poradnik $i$ Biuletyn BN dla bibliotekarzy ("The BNP Guide and Bulletin for Librarians"), which would be sent to librarians on a daily basis to provide them with the latest information they needed.

On June 3 the BNP announced that its reading rooms would reopen on Monday, June 8, 2020. Out of concern for the safety of the Library's readers and staff, new rules for using the reading rooms during the epidemic were introduced. Until June 21 only readers who already had BNP library cards could use the reading rooms; after that date new cards could be issued.

According to the new rules, readers were obliged to disinfect their hands after entering the BNP and cover their mouth and nose. In order to use the reading rooms it was necessary to make a reservation in advance. Since August 2018 modernisation and renovation works have been underway at the BNP and access to the collections is only possible in small, temporary reading rooms with space for 90 readers ${ }^{29}$. Due to the small size of the temporary reading rooms and the need to maintain two metres distance between readers, fewer desks were available in the reading rooms following the reopening on June 8 , and readers had to reserve a desk for one of the following time slots:

- 8.30 a.m. to 12.30 p.m.

- 1.30 to 5.30 p.m.

- 6.30 to 8.30 p.m..$^{30}$

${ }^{27}$ The BNP reopened its interlibrary loan facility in May. Protokół nr 14 posiedzenia Kolegium Biblioteki Narodowej z dnia 26 maja 2020 r. (14th Minutes of the Meeting of the Kolegium of the BNP, May 26, 2020)

28 https://www.bn.org.pl/aktualnosci/3993-rekomendacje-biblioteki-narodowej-dotyczace-otwarcia-czyteln-w-bibliotekach.html

${ }^{29}$ Due to the rise in infections and the need to maintain more space between readers, there are currently 28 places available in the reading room (as per October 30, 2020).

${ }^{30}$ Due to the low number of reservations this system was abandoned the following day, in line 
During the hour-long breaks, desks and other surfaces were disinfected and the reading room ventilated ${ }^{31}$. Every day 50 places were available, until the sanitary regulations were relaxed. It was announced that if the number of readers was smaller than the number of available desks, the reservation system would be abandoned. The reservation system was launched on Friday, June 5 at 10 a.m.

To give the maximum number of readers access to the the BNP's unique collections, readers were allowed to order two items (that is, books and journals from the nineteenth to twenty-first centuries) per reserved time slot. Further orders could be placed once these items had been returned. To limit the number of readers, it was decided that orders for early printed books and most microfilms would be sent for free digitisation and made available on POLONA within a week of the order being placed. Thanks to these measures the waiting time for a desk in the reading room did not exceed one day.

Manuscripts were available for consultation in the Heritage Collections Reading Room between 8.30 a.m. and 5.30 p.m. by readers who had booked a visit in advance by email. To consult graphic materials, maps and musical scores, readers had to make an appointment with the head of the collection in question ${ }^{32}$.

On June 10 the BNP published a statement on the organisation of events in libraries. It recommended that open air and indoor events only be held in areas where there were no cases of coronavirus or where the number of such infections was clearly falling. The sanitary rules set out in the regulations applied. Online events were still to be preferred ${ }^{33}$.

At the meeting of the Kolegium on June 23, Tomasz Makowski drew attention to the situation regarding the pandemic in the Mazovian Voivodeship, where there was a drop in the number of infections. He stressed, however, that the Ministry of Health and the WHO were warning about a second wave of the pandemic in the autumn. He asked the heads of departments to make plans for the work of their units in the event that restrictions were reintroduced due to a significant rise in the number of infections. He further called for rooms to aired frequently, lifts

with the announcement. It was reintroduced on August 26 following an increase in the number of people wanting to use the reading rooms and the formation of queues. This increase in turnout was probably influenced by the fact that the reading rooms of the University Library in Warsaw had remained closed from March 11, 2020, and did not even reopen when the number of infections fell during the holidays.

${ }^{31}$ On June 21 the ventilation of reading rooms was reduced to half an hour and the time slots adjusted as follows: 8.30 a.m. to 1 p.m., 1.30 to 6 p.m., 6.30 to 8.30 p.m.

${ }^{32}$ https://www.bn.org.pl/aktualnosci/3998-czytelnie-biblioteki-narodowej-beda-otwarte-od-8czerwca-w-godz.-8.30-20.30.html

${ }^{33}$ https://www.bn.org.pl/aktualnosci/4007-rekomendacje-biblioteki-narodowej-dotyczace-organizowania-wydarzen-w-bibliotekach.html 
not be used unless necessary and door handles and surfaces to be disinfected ${ }^{34}$.

Following the introduction of additional restrictions from Saturday, August 8, 2020, in the 19 districts in Poland ("yellow zones" and "red zones") which had seen the largest increase in coronavirus infections, the $\mathrm{BNP}$ recommended that libraries located in these areas follow the general recommendations and introduce new rules for the safety of their employees and readers. Specifically, libraries in both zones must:

- Strictly ensure that librarians and readers covered their mouth and nose and used hand disinfectants or put on disposable gloves before entering the library

- Rigorously ensure a minimum of 1.5 metres was maintained between people in all public spaces

- Continually ventilate rooms, especially if they are small (including toilets and corridors if possible)

The BNP further recommended that libraries in the red zone closed their reading rooms and did not offer free access to their collections, instead offering only lending and returning facilities. The Rozporządzenie Rady Ministrów z dnia 7 sierpnia 2020 r. w sprawie ustanowienia określonych ograniczeń, nakazów i zakazów w związku z wystąpieniem stanu epidemii (Ordinance of the Council of Ministers of August 7, 2020, on the establishment of certain restrictions, orders and prohibitions in connection with the occurrence of a state of epidemic) limited the number of participants in events and meetings to 150 people throughout the entire country, 100 people in districts in the yellow zone, and 50 people in the red zone. In libraries in the red and yellow zones, the BNP recommended that events and meetings are only organised online ${ }^{35}$.

Following an increase in infections and the inclusion of Warsaw in the red zone from October 17, and the whole country from October 24, the BNP tightened its sanitary regime and, once again, as many workers as possible were shifted to working from home. However, it has remained possible to use the reading rooms thanks to the sanitary regime effectively maintained by the Library's employees and readers. The BNP's recommendations for libraries in Poland are also amended on an ongoing basis.

The situation of the BNP in the nine months since the pandemic began is good compared to other institutions, which have been hit harder by the virus. The first case of a BNP employee being infected was on October 21. Given that the BNP employs 800 people, has many contacts with other people and welcomes visitors from various parts of Poland every

\footnotetext{
${ }^{34}$ Protokół nr 18 posiedzenia Kolegium Biblioteki Narodowej z dnia 23 czerwca 2020 r. (18th Minutes of the Meeting of the Kolegium of the BNP, June 23, 2020)

${ }^{35} \mathrm{https} / / / \mathrm{www}$.bn.org.pl/aktualnosci/4036-rekomendacje-bn-dla-bibliotek-w-powiatachobjetych-specjalnymi-obostrzeniami-podczas-epidemii.html
} 
day, this confirms that the decisions made so far during the pandemic and the self-discipline of our staff, who are aware of the seriousness of the situation, have had a positive impact ${ }^{36}$. We would draw attention to the excellent cooperation between the directors, heads of departments, other staff, trade unions and the Ministry of Culture and National Heritage ${ }^{37}$. The investments made over recent years as part of the reorientation of the BNP towards digital services were also important; during the pandemic they proved invaluable.

Throughout the pandemic, the Director General of the BNP was in constant contact with the directors of other national libraries and public networks in Europe, the chairpersons of conferences of directors of various types of libraries and the directors of Poland's leading libraries, in particular the Director of the Jagiellonian Library, Poland's largest and oldest university library.

During the pandemic it has been possible for most tasks to continue without delays thanks to the new way in which work is organised. The magnificent collection of manuscripts of the Counts Tarnowski Library from Dzikow Castle has been purchased and Professor Leszek Kołakowski's library transported from Oxford to Poland. The BNP has received new grants for digitisation, completed the relocation of its manuscript and early printed book collections from the Palace of the Commonwealth, where a complete renovation of the building began in August 2020, to the BNP's main building. The BNP has also continued with the modernisation and renovation of the reading rooms in the main building.

${ }^{36}$ At the time of writing (October 30, 2020), four BNP employees have so far been diagnosed with COVID-19.

${ }^{37}$ The heads and other staff of the services involved in the running of the BNP played a particularly important role here, namely the Zakład Administracyjno-Gospodarczy (Administrative and Economic Department), the Zakład Technologii Informatycznych (Information Technology Department), the Biuro Spraw Pracowniczych (Office of Workers' Affairs), and also Barbara Morawiec, responsible for the BNP's information policy. The BNP's success during this difficult period is to a large extent due to their contribution. 